\title{
Direct-Deposited Graphene Oxide on Dental Implants for Antimicrobial Activities and Osteogenesis
}

\author{
WooHyung Jang (iD) \\ Hee-Seon Kim' \\ Khurshed Alam (D) ${ }^{2}$ \\ Min-Kyung $\mathrm{Ji}^{3}$ \\ Hoon-Sung Cho $\mathbb{1 D}^{2}$ \\ Hyun-Pil Lim'
}

'Department of Prosthodontics, School of Dentistry, Chonnam National University, Gwangju, Korea; ${ }^{2}$ Department of Materials Science and Engineering, Chonnam National University, Gwangju, 61186, Korea; ${ }^{3}$ Optoelectronics Convergence Research Center, Chonnam National University, Gwangju, 6II86, Korea
Correspondence: Hyun-Pil Lim Department of Prosthodontics, School of Dentistry, Chonnam National University,

Gwangju, 61186, Korea

Tel +82-10-2645-7528

Fax +82-62-530-5577

Email mcnihil@jnu.ac.kr

Hoon-Sung Cho

Department of Materials Science and

Engineering, Chonnam National University,

Gwangju, 61 I86, Korea

$\mathrm{Tel} / \mathrm{Fax}+82-62-530-1717$

Email cho.hoonsung@jnu.ac.kr
Objective: To determine the effects of graphene oxide (GO) deposition (on a zirconia surface) on bacterial adhesion and osteoblast activation.

Methods: An atmospheric pressure plasma generator (PGS-300) was used to coat $\mathrm{Ar} / \mathrm{CH}_{4}$ mixed gas onto zirconia specimens $(15-\mathrm{mm}$ diameter $\times 2.5-\mathrm{mm}$ thick disks $)$ at a rate of $10 \mathrm{~L} /$ min and $240 \mathrm{~V}$. Zirconia specimens were divided into two groups: uncoated (control; $\mathrm{Zr}$ ) group and GO-coated (Zr-GO) group. Surface characteristics and element structures of each specimen were evaluated by field emission scanning electron microscope (FE-SEM), X-ray photoelectron spectroscopy (XPS), Raman spectroscopy, and contact angle. Additionally, crystal violet staining was performed to assess the adhesion of Streptococcus mutans. WST-8 and ALP (Alkaline phosphatase) assays were conducted to evaluate MC3T3-E1 osteoblast adhesion, proliferation, and differentiation. Statistical analysis was calculated by the MannWhitney $U$-test.

Results: FE-SEM and Raman spectroscopy demonstrated effective GO deposition on the zirconia surface in $\mathrm{Zr}-\mathrm{GO}$. The attachment and biofilm formation of $S$. mutans was significantly reduced in $\mathrm{Zr}-\mathrm{GO}$ compared with that of $\mathrm{Zr}(P<0.05)$. While no significant differences in cell attachment of MC3T3-1 were observed, both proliferation and differentiation were increased in $\mathrm{Zr}-\mathrm{GO}$ as compared with that of $\mathrm{Zr}(P<0.05)$.

Significance: GO-coated zirconia inhibited the attachment of $S$. mutans and stimulated proliferation and differentiation of osteoblasts. Therefore, GO-coated zirconia can prevent peri-implantitis by inhibiting bacterial adhesion. Moreover, its osteogenic ability can increase bone adhesion and success rate of implants.

Keywords: graphene oxide, GO, zirconia implant, biofilm formation, osteoblast, nonthermal atmospheric pressure plasma

\section{Introduction}

Peri-implantitis is the most significant cause of early or late implant failures. ${ }^{1}$ It occurs when bacteria coagulate irreversibly on the teeth or implants and leads to the formation of a bacterial biofilm on the surface, which can lead to bone loss. ${ }^{2-4}$ To treat peri-implantitis, mechanical methods which remove the biofilm using carbon fiber curettes and chemical methods which kill the bacteria via disinfection treatment and antibiotics ${ }^{5-7}$ are used together for effective results. Recently, to prevent peri-implantitis, many attempts have been made to treat the surface of implants with antibacterial materials. ${ }^{8}$ Graphene, a honeycomb-lattice monolayer comprising aromatic ring carbon atoms, is a potential biomaterial owing to its unique physical and 
Graphical Abstract

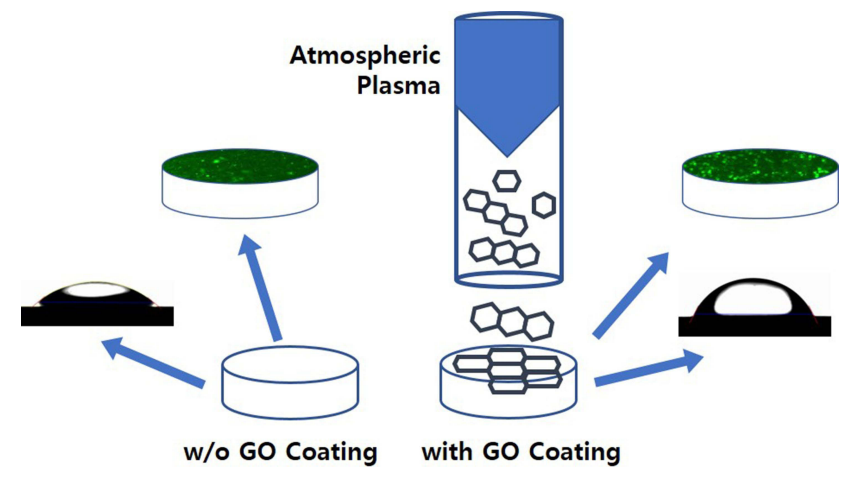

chemical properties. ${ }^{9-11}$ In contrast, unlike graphene, graphene oxide (GO) has hydrophilic tendency because of its functional groups (ie, carboxyl, hydroxyl, and epoxy groups); an antibiotic effect; and it promotes bone production through osteoblast activation. ${ }^{12-17}$ Existing methods of GO fabrication include chemical or physical exfoliation from bulk graphite, ${ }^{18,19}$ chemical vapor deposition using a metal catalyst, ${ }^{20}$ and Hummer's method. ${ }^{21,22}$ However, these methods have some disadvantages including high pollution, low efficiency, potential residual solution byproducts used in GO production, and the generation of harmful inflammable gases such as $\mathrm{NO}_{2}, \mathrm{~N}_{2} \mathrm{O}_{4}$, and $\mathrm{ClO}_{2} \cdot{ }^{23-25}$

When living tissues are treated with plasma (a charged gas because of ionized energy), their wettability and mechanical and biological properties can be modified. ${ }^{26}$ Plasma treatment improves biocompatibility, cell adhesion, and increases bacterial resistance. ${ }^{27-30}$ In this study, we developed a new method combining plasma treatment and graphene synthesis. Rho et al reported the deposition of an argon plasma-based GO on a titanium surface, improving biocompatibility and promoting differentiation of fibroblasts (NCTC clone 929) and MC3T3-E1 cells. ${ }^{31}$ This simple and costeffective method did not require any additives or produced any by-products. Zirconia, one of the primary dental materials, has low toxicity and corrosivity and high antibiotic activity and biocompatibility. ${ }^{32,33}$ Owing to these features, zirconia implants are currently being studied extensively. The increase in clinical applications of zirconia implants is because of its higher success rate $^{34}$ and comparable fracture strength to that of titanium, which has been widely used in the past. ${ }^{35}$
However, to the best of our knowledge, the combined effects of GO and zirconia have not yet been reported. Therefore, this study evaluated the effects of a biocompatible plasma-based GO-coated $\mathrm{Zr}$ surface on biofilm formation and osteoblast activation.

\section{Materials and Methods Experimental Materials Samples}

Zirconia (Zirmon, Kuwotech, Gwangju, Korea) was produced into disk-shaped specimens (diameter: $15 \mathrm{~mm}$, thickness: $2.5 \mathrm{~mm}$ ). The surface of each specimen was prepared using \#800 SiC (silicon carbide) paper to obtain an even surface. All specimens were cleaned with acetone, alcohol, and distilled water for 20 min using an ultrasonic cleaner. Thereafter, the specimens were dried at room temperature $\left(20-25^{\circ} \mathrm{C}\right)$ and sterilized using an autoclave (HS-3460SD, Hanshin Medical Co, Korea). Two groups of zirconia specimens were prepared: pure zirconia specimens which were not coated with GO (Group Zr) and zirconia specimens which were coated with GO for 1 min (Group Zr-GO).

\section{GO-Coated Zirconia}

Zirconia specimens were coated with GO using an atmospheric pressure plasma generator (PGS-300, Expantech Co, Korea). Argon gas (4 L/min) and methane gas $(3.5 \mathrm{~mL} / \mathrm{min})$ were mixed in a quartz tube and coated on the surface at $240 \mathrm{~V}$ at the rate of $10 \mathrm{~L} / \mathrm{min}$. The distance between the specimen and plasma was maintained at $25 \mathrm{~mm}$, and the plasma was rotated and simultaneously 
Table I Parameters of the Atmospheric Plasma Generator

\begin{tabular}{|l|l|}
\hline Parameter & Value \\
\hline Average working power (W) & 240 \\
Voltage (V) & 27 \\
Frequency (MHz) & 900 \\
Atmospheric pressure (Torr) & 760 \\
Electrode type & Electrodeless \\
Cooling type & Air-cooled \\
Plasma density & $10^{15} / \mathrm{cm}^{3}$ \\
\hline
\end{tabular}

reciprocated from side-to-side to ensure even application of GO on the surface (Table 1, Figure 1).

\section{Assessment of Surface Characteristics}

The surface of zirconia was coated with platinum in vacuum for $60 \mathrm{~s}$ using a sputter coater (E-1030, Hitachi, Japan) and was observed using a field emission scanning electron microscope (FE-SEM; S-4700, Hitachi, Japan).

The thicknesses, atomic components, and chemical bonds of the specimens were assessed using X-ray photoelectron spectroscopy (XPS; VG Multilab 2000, Thermo Scientific, UK). The peak areas of atomic elements observed in the specimens were normalized and expressed as quantitative proportions.

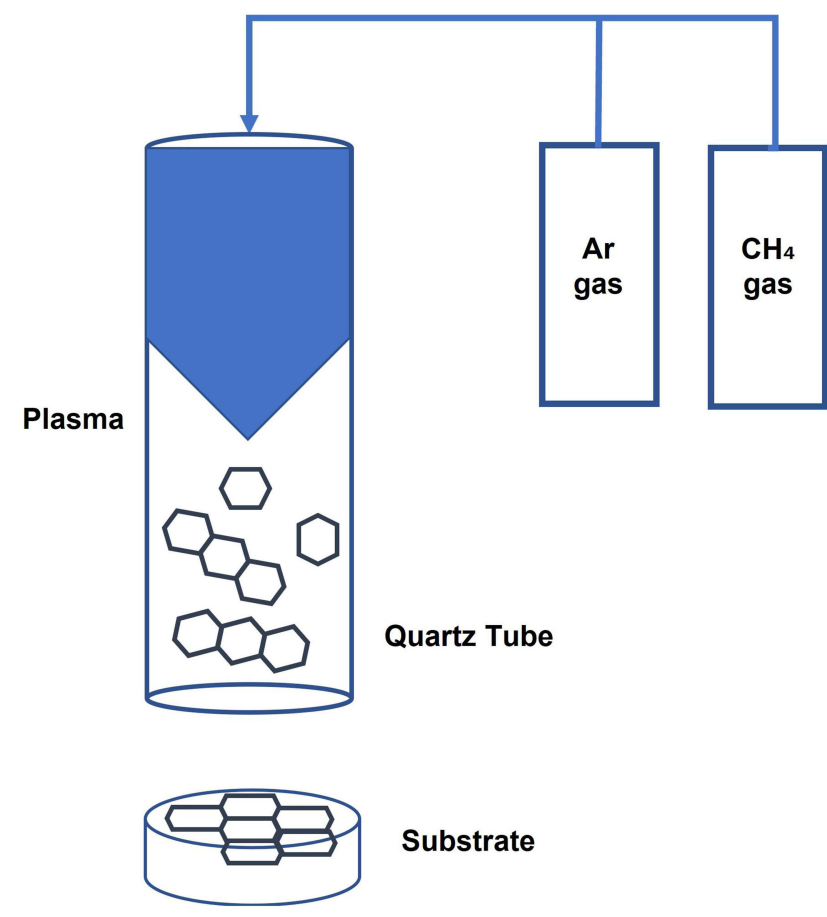

Figure I Schematic diagram of GO coating with atmospheric plasma generator.
The shapes, thicknesses, and roughness of specimens were observed using a nanosurface 3D optical profiler (NV-E1000, Nano System, Korea), and for each group three specimens were measured using three different areas.

Raman spectroscopy was performed to assess the status of the GO coating on the zirconia surface at $532.13 \mathrm{~nm}$ using a Raman spectrometer (NRS-5100, JASCO, Japan), and the contact angle (Phoenix 300, SEO Inc., Korea) was measured to compare the hydrophilicity of the surfaces. For each group, three specimens were measured and their average contact angles were analyzed (Surfaceware 9 software, SEO Inc, Korea)

\section{Assessment of Bacterial Adhesion Bacterial Culture}

To evaluate biofilm thickness inhibition, Streptococcus mutans (KCOM 1504 obtained from the Korean Collection for Oral Microbiology (KCOM, Korea)), a gram-positive bacterium involved in early biofilm formation, was used. S. mutans was cultured at $37{ }^{\circ} \mathrm{C}$ in a culture chamber (LIB-150M, DAIHAN Labtech Co., Korea) using a BHI medium (Brain Heart Infusion, Becton, Dickinson and Company, Sparks, MD, USA).

\section{Bacterial Inoculation}

Every specimen was sterilized in an autoclave (HS-3460SD, Hanshin Medical Co, Korea) for $2 \mathrm{~h}$ and disinfected under $\mathrm{UV}$ for $24 \mathrm{~h}$. Subsequently, for each group, eight specimens were placed in a 24-well plate (SPL Life Sciences Co., Ltd., Korea), and each specimen was inoculated with $S$. mutans $\left(1.5 \times 10^{7} \mathrm{CFU} / \mathrm{mL}\right)$ and cultured for $24 \mathrm{~h}$.

\section{Bacterial Adhesion Assessment}

After culturing, the culture medium was removed, and the specimens were cleaned with Phosphate Buffer Saline (PBS) solution twice. Adherent bacteria were dyed with $0.3 \%$ crystal violet solution by dispensing $500 \mu \mathrm{L}$ of the solution to each specimen. After $10 \mathrm{~min}$, the crystal violet solution was removed, and the remaining solution was cleaned three times with PBS solution. Subsequently, the specimens were dried for $15 \mathrm{~min}$, and $500 \mu \mathrm{L}$ of demineralized solution ( $80 \%$ ethyl alcohol $+20 \%$ acetone) was dispensed. The specimens were tightly sealed and stirred for $1 \mathrm{~h}$. After stirring, $200 \mu \mathrm{L}$ of each specimen was dispensed into a 96-well plate (SPL Life Sciences Co, Ltd, Korea), and their absorbance was measured at $595 \mathrm{~nm}$ using ELISA (VersaMax ELISA Microplate Reader, Molecular Device, CA, USA). 
Bacteria adhesion was visually assessed using the LIVE/ DEAD $^{\circledR}$ BacLight $^{\mathrm{TM}}$ Bacterial Viability Kit (SYTO 9 ${ }^{\circledR}$, Molecular Probes Europe BV, Netherlands). After culturing, the bacteria and the remaining culture medium were cleaned with PBS solution. To each specimen, $200 \mu \mathrm{L}$ of fluorescence reagent (SYTO 9 dye: propidium iodide: $\mathrm{dH}_{2} \mathrm{O}=1.5 \mu \mathrm{L}$ : 1.5 $\mu \mathrm{L}: 1.0 \mathrm{~mL}$ ) was injected. The well plate was sealed with aluminum foil to block the light and was dyed at room temperature $\left(20-25^{\circ} \mathrm{C}\right)$ for $15 \mathrm{~min}$. Subsequently, the remaining dye solution was cleaned with PBS solution and the adherent bacteria were observed using a confocal laser scanning microscope (Leica TCS SP5 AOBS/tandem, Leica, Germany) and the thickness of the biofilm formed on the specimen was measured through an z-axis depth profiling (Leica LAS AF software, Leica Microsystems, Bensheim, Germany).

\section{Assessment of Osteoblast Viability Cell Culture}

MC3T3-E1 osteoblasts (MC3T3-E1 subclone 4, ATCC CRL2593, USA) were cultured at $37{ }^{\circ} \mathrm{C}$ in a $5 \% \mathrm{CO}_{2}$ incubator (Forma Series II 3111 Water Jacketed $\mathrm{CO}_{2}$ Incubator, Thermo Fisher Scientific Inc., USA) using an alpha minimum essential medium ( $\alpha$-MEM; Gibco-BRL, Grand Island, USA) containing 10\% fetal bovine serum (FBS) and $100 \mathrm{U} / \mathrm{mL}$ penicillin.

\section{Cell Adhesion/Proliferation}

For each group, eight specimens were prepared and fixed in a 24-well plate. Cultured cells $\left(4 \times 10^{4}\right.$ cells $\left./ \mathrm{mL}\right)$ were dispensed on each specimen and incubated at $37{ }^{\circ} \mathrm{C}$ in a $5 \%$ $\mathrm{CO}_{2}$ incubator. After dispensing the cells, cell adhesion and proliferation were assessed on the 1st and the 5th day, respectively. Before assessment, the surface was cleaned with PBS to remove any remaining culture medium and non-adherent cells. Subsequently, $1 \mathrm{~mL}$ of fresh medium and $100 \mathrm{uL}$ of WST-8 reagent (EZ-Cytox, Itsbio, Inc., Korea) were added to each specimen and incubated at $37{ }^{\circ} \mathrm{C}$ in a $5 \% \mathrm{CO}_{2}$ incubator. After $10 \mathrm{~min}$, when color development was observed, $100 \mu \mathrm{L}$ of each specimen was dispensed into a 96-well plate and their absorbance was measured at $450 \mathrm{~nm}$ using an absorbance reader (VersaMax ELISA Microplate Reader, Molecular Devices, USA).

\section{Cell Differentiation}

For each group, eight specimens disinfected with $\mathrm{UV}$ rays were fixed in a 24-well plate. Cultured cells $\left(4 \times 10^{4}\right.$ cells $\left./ \mathrm{mL}\right)$ were dispensed on each specimen and cultured at $37^{\circ} \mathrm{C}$ in a $5 \% \mathrm{CO}_{2}$ incubator. Cell differentiation was assessed on the 21 st day after culturing. Subsequently, the surface was cleaned with PBS to remove the remaining culture medium and nonadherent cells. Each specimen was treated with $200 \mu \mathrm{L}$ of ALP assay buffer and cultured at $37^{\circ} \mathrm{C}$ in a $5 \% \mathrm{CO}_{2}$ incubator for $1 \mathrm{~h}$. Subsequently, $80 \mu \mathrm{L}$ of each specimen was dispensed into a 96-well plate and treated with $50 \mu \mathrm{L}$ of pNPP solution. The specimens were cultured at $37^{\circ} \mathrm{C}$ in a $5 \% \mathrm{CO}_{2}$ incubator for $1 \mathrm{~h}$, treated with $20 \mu \mathrm{L}$ of stop solution, and their absorbance was measured at $405 \mathrm{~nm}$.

\section{Statistical Analysis}

Statistical analysis was conducted using SPSS 21.0 (SPSS Inc., Chicago, IL, USA). The significance test depending on the treatment of GO coating did not meet the normality, thus the Mann-Whitney $U$-test, a non-parametric test, was performed. The significance of all data collected was tested at a significance level of $P<0.05$.

\section{Results}

\section{Surface Characteristics}

Surface characteristics were observed with a scanning electron microscope (SEM) (Figure 2A and B). Group Zr exhibited an evenly polished surface, whereas in Group Zr-GO, GO exhibited a cloudy appearance on the surface.

Surface roughness was measured using a nanosurface 3D optical profiler (Figure 2C and D), with Group Zr-GO exhibiting high roughness $(n=3)$. The Ra values of Group $\mathrm{Zr}$ and $\mathrm{Zr}-\mathrm{GO}$ were $130.564 \pm 50.352 \mathrm{~nm}$ and $184.084 \pm$ $45.153 \mathrm{~nm}$, respectively.

The atomic components of the surface were analyzed by XPS (Figure 3). Both Group Zr and Group Zr-GO exhibited oxygen $(\mathrm{O})$, carbon $(\mathrm{C})$, and zirconia $(\mathrm{Zr})$ peaks. The element ratio analysis demonstrated that the $\mathrm{Zr}$ group consisted of $43.35 \%$ carbon, $45.28 \%$ oxygen, and $11.37 \%$ zirconia; and the $\mathrm{Zr}-\mathrm{GO}$ group consisted of $86.78 \%$ carbon, $12.08 \%$ oxygen, and $1.13 \%$ zirconia. Group Zr-GO showed a high carbon peak, resulting in a $2 \mathrm{x}$-high carbon ratio.

The Raman spectrum analysis (Figure 4) observed unique peaks of $\mathrm{GO}$, including $\mathrm{D}$ band $\left(\sim 1350 \mathrm{~cm}^{-1}\right)$, $\mathrm{G}$ band $\left(\sim 1590 \mathrm{~cm}^{-1}\right)$, and $2 \mathrm{D}$ band $\left(\sim 2690 \mathrm{~cm}^{-1}\right)$. Compared with Group Zr, Group Zr-GO showed a significant increase in the contact angle (39.27 \pm $0.914^{\circ}$ vs $64.64 \pm 0.310^{\circ} ; P<0.05$ ) (Figure 5).

\section{Inhibition of Biofilm Formation}

In the crystal violet assay, the $S$. mutans adhesion in Group $\mathrm{Zr}$-GO significantly decreased compared to that of Group 

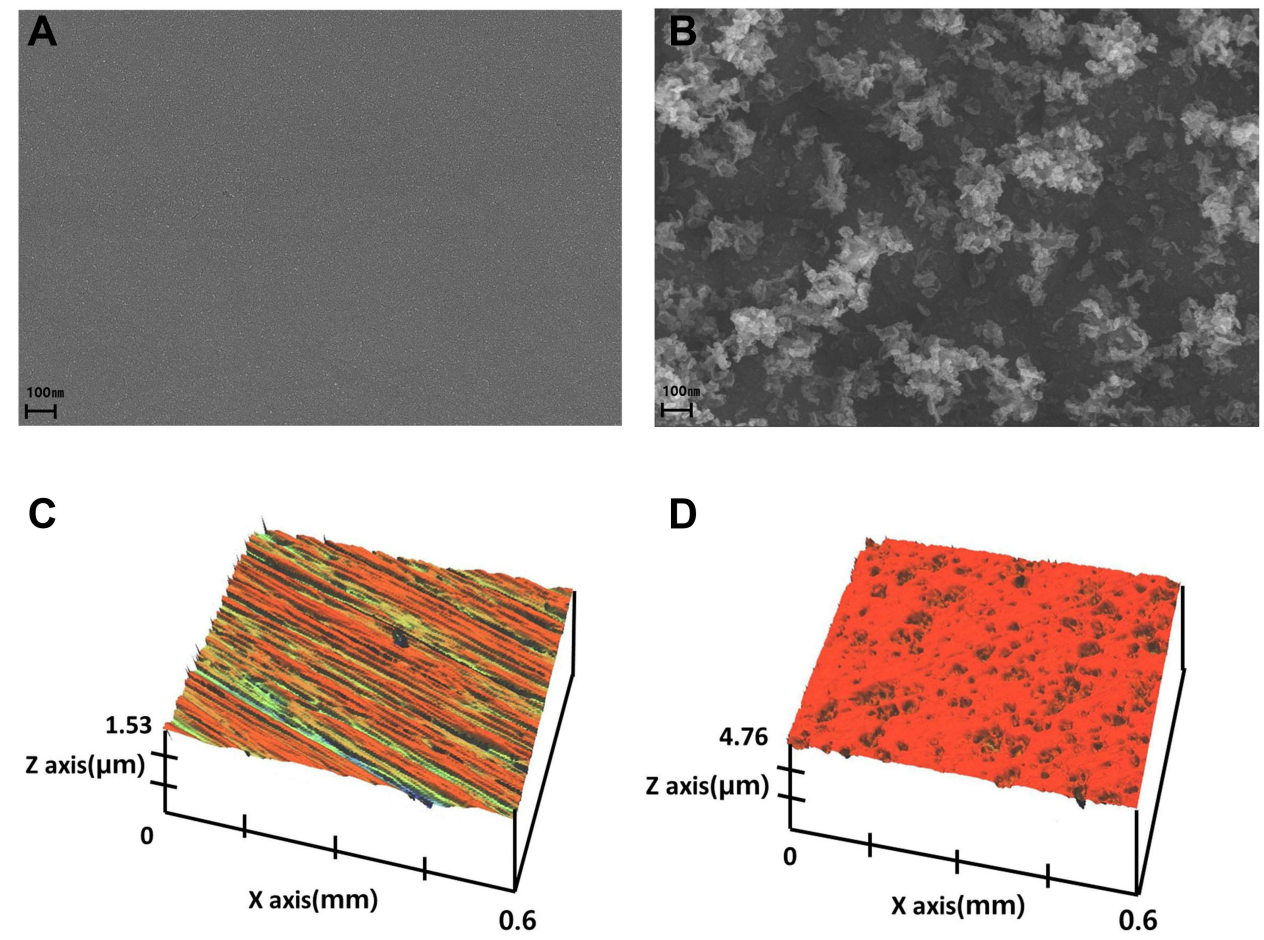

Figure 2 FE-SEM images of $(\mathbf{A})$ control $(\mathrm{Zr})$ and $(\mathbf{B}) \mathrm{GO}$-coated zirconia $(\mathrm{Zr}-\mathrm{GO})$ groups $(\times 50 \mathrm{~K})$. Three-dimensional surface morphology roughness images of $(\mathbf{C}) \mathrm{Zr}$ and (D) Zr-GO groups.

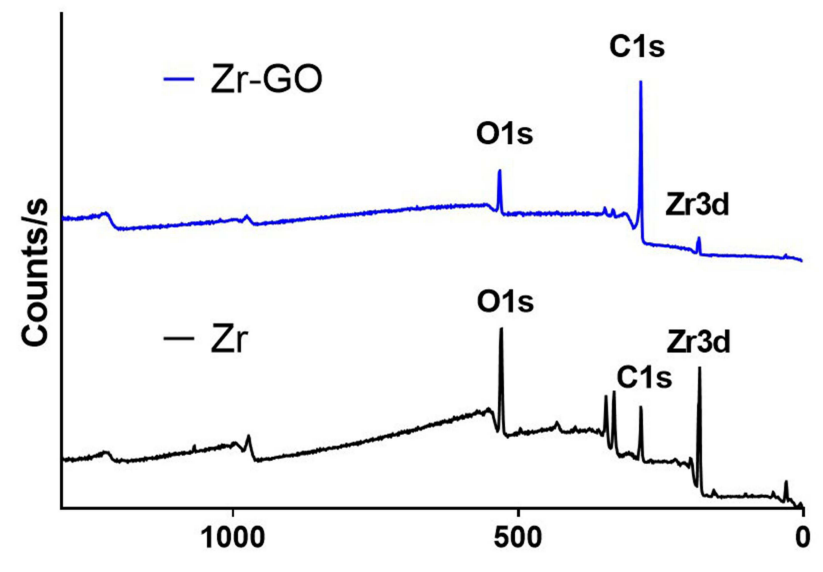

Binding Energy (eV)

Figure 3 XPS profiles of GO-coated zirconia surface $(\mathrm{Zr}-\mathrm{GO})$ and control $(\mathrm{Zr})$ groups.

$\operatorname{Zr}(P<0.001)$ (Figure 6A). Additionally, the thickness of biofilm in Group Zr-GO decreased significantly (Group Zr $=16.99 \pm 3.36 \mu \mathrm{m}$, Group $\mathrm{Zr}-\mathrm{GO}=11.20 \pm 0.74 \mu \mathrm{m} ; P<$ 0.05) (Figure 6B). Finally, using the LIVE/DEAD ${ }^{\circledR}$ BacLight $^{\mathrm{TM}}$ Bacterial Viability Kit. (Figure 6C and D), a greater number of viable cells were observed in $\mathrm{Zr}$ group compared with that of the $\mathrm{Zr}-\mathrm{GO}$ group.

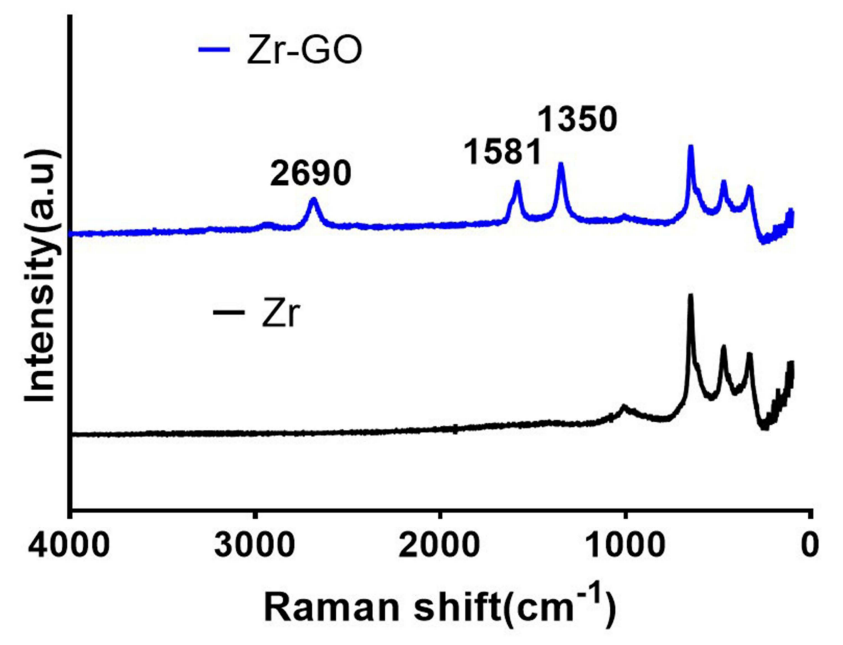

Figure 4 Raman spectrum of GO-coated zirconia surface ( $\mathrm{Zr}-\mathrm{GO})$ and control $(Z r)$ groups, showing D $\left(1350 \mathrm{~cm}^{-1}\right), G\left(1581 \mathrm{~cm}^{-1}\right)$, and 2D peak at $2690 \mathrm{~cm}^{-1}$ of GO band.

\section{Osteoblast Activation}

Effects on Cell Adhesion, Proliferation, and Differentiation

To assess osteoblast adhesion and proliferation, the WST-8 assay was performed. For adhesion, a absorbance of Group $\mathrm{Zr}$ (2.18) was observed with a little higher than that of Group ZrGO (0.207); however, this difference was not statistically 

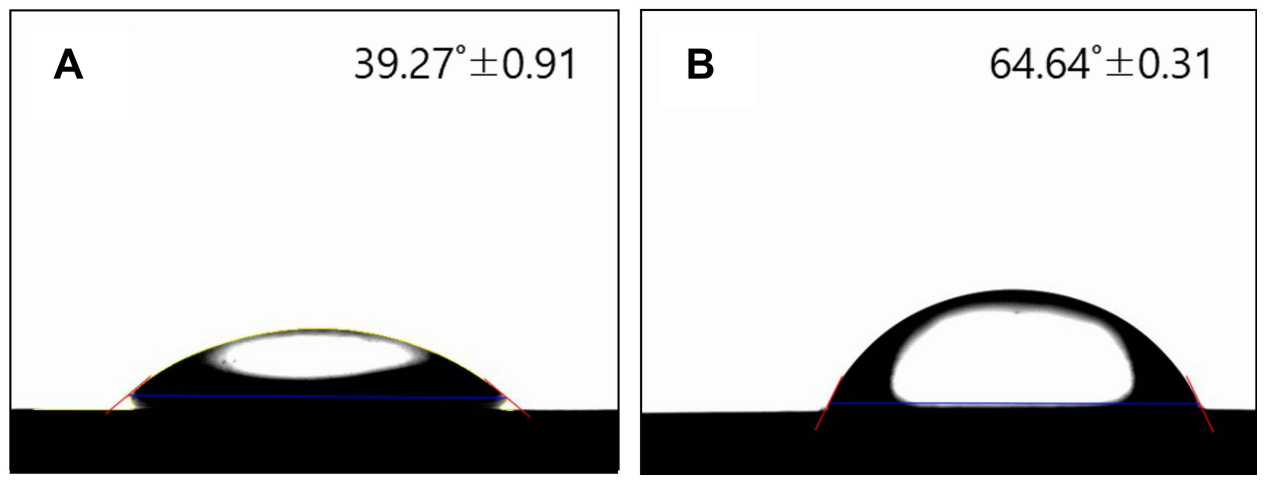

Figure 5 Water droplet on surface of the contact angle. (A) Control ( $\mathrm{Zr}$ ) group; (B) GO-coated zirconia (Zr-GO) group. The GO-coated zirconia (Zr-GO) group is hydrophobic compared to the control (Zr) group, and the contact angle was significantly increased.
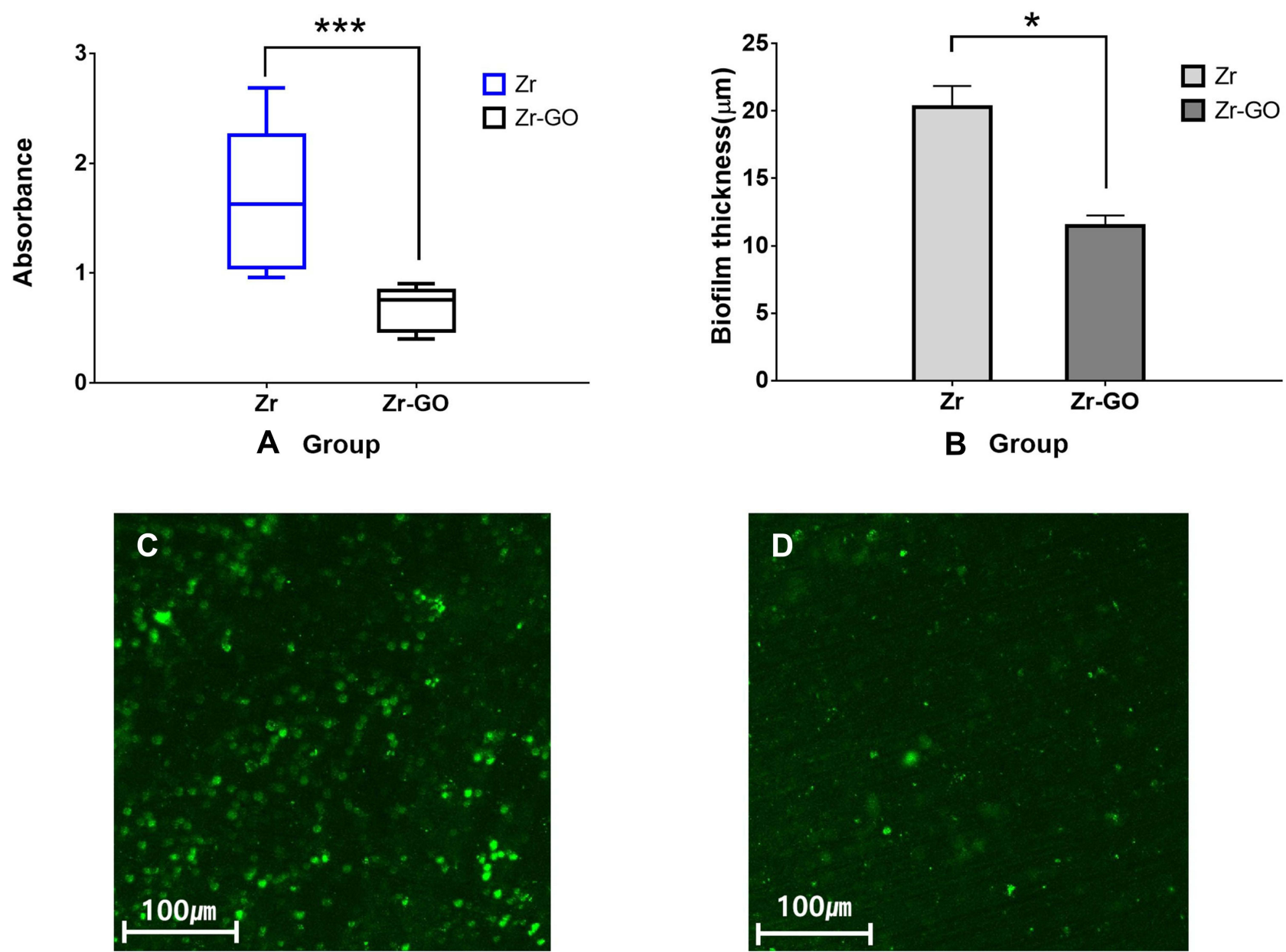

Figure 6 (A) Bacterial adhesion on GO-coated zirconia $(\mathrm{Zr}-\mathrm{GO})$ and control $(\mathrm{Zr})$ surfaces, as measured by crystal violet assay $(\mathrm{n}=8)$. $($ B) Biofilm thickness of Streptococcus mutans on $\mathrm{Zr}$-GO and $\mathrm{Zr}$ surfaces $(\mathrm{n}=3)$. (C and $\mathbf{D})$ Viability of Streptococcus mutans biofilm on $(\mathbf{C}) \mathrm{Zr}$ and $(\mathbf{D}) \mathrm{Zr}$ - $\mathrm{GO}$ surfaces $(\mathrm{n}=3)$. Green fluorescence indicates viable cells. $* P<0.05$, ***P $<0.001$; Mann-Whitney U-test.

significant (Figure 7A). Contrarily, for proliferation, a significantly higher absorbance level was observed in Group Zr-GO (0.322) as compared with that of Group Z Zr (0.309) $(P<0.05)$ (Figure 7B). Cell differentiation was assessed using the ALP activity assay. As shown in Figure 7C, the absorbance level of Group Zr-GO (0.219) was significantly higher than that of Group $\mathrm{Zr}(0.190)$ $(P<0.05)$. 

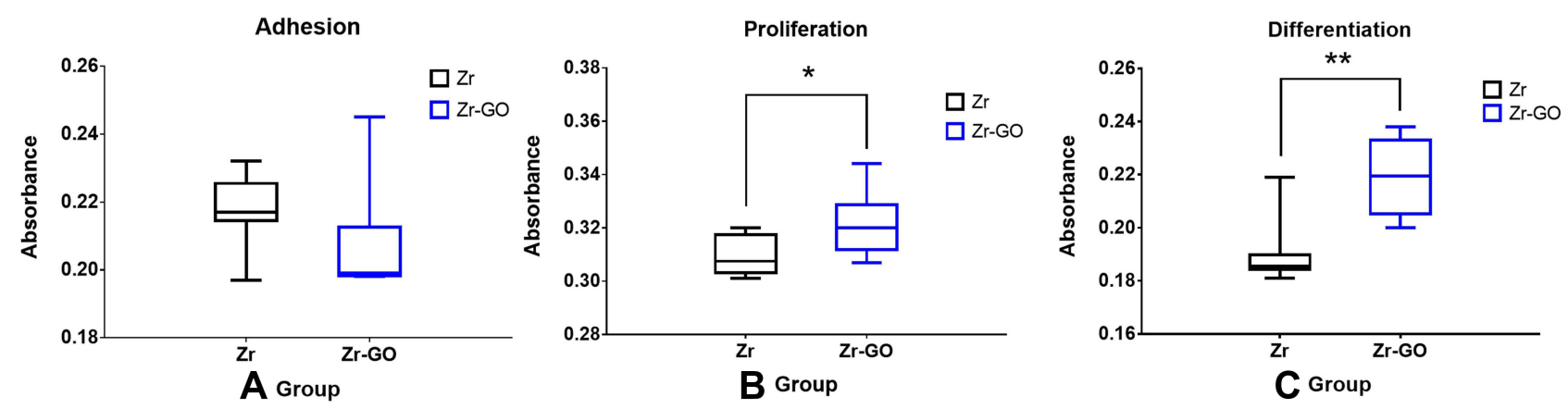

Figure 7 (A) Cell adhesion (measured using WST-8 assay at $24 \mathrm{~h}$ ) on graphene oxide-coated zirconia $(\mathrm{Zr}-\mathrm{GO})$ and control $(\mathrm{Zr})$ surfaces $(\mathrm{n}=8)$. $(\mathbf{B})$ Cell proliferation (measured using WST-8 assay at $120 \mathrm{~h}$ ) on $\mathrm{Zr}$ and $\mathrm{Zr}$-GO surfaces $(\mathrm{n}=8)$. $(\mathbf{C})$ Cell differentiation (measured by ALP assay at $2 \mathrm{I}$ days) on $\mathrm{Zr}$ and $\mathrm{Zr}$ - $\mathrm{GO}$ surfaces $(\mathrm{n}=8$ ). $* P<0.05$, $* * P<0.01$; Mann-Whitney $U$-test.

After the 5 days of cell culture, the proliferation of cell morphology were observed with a scanning electron microscope (SEM). It showed that the cells exhibited proliferation and spreading on the surfaces and the cells proliferated more in the group $\mathrm{Zr}$-GO (Figure 8B-D). Than in the group $\mathrm{Zr}$ (Figure $8 \mathrm{~A}-\mathrm{C}$ ) and a lot of cell projections were formed.

\section{Discussion}

Implants are very useful for replacing missing teeth. However, after implantation, bone resorption or inflammation of the surrounding gingiva often occurs because of bacterial infection. Therefore, to prevent this, researchers
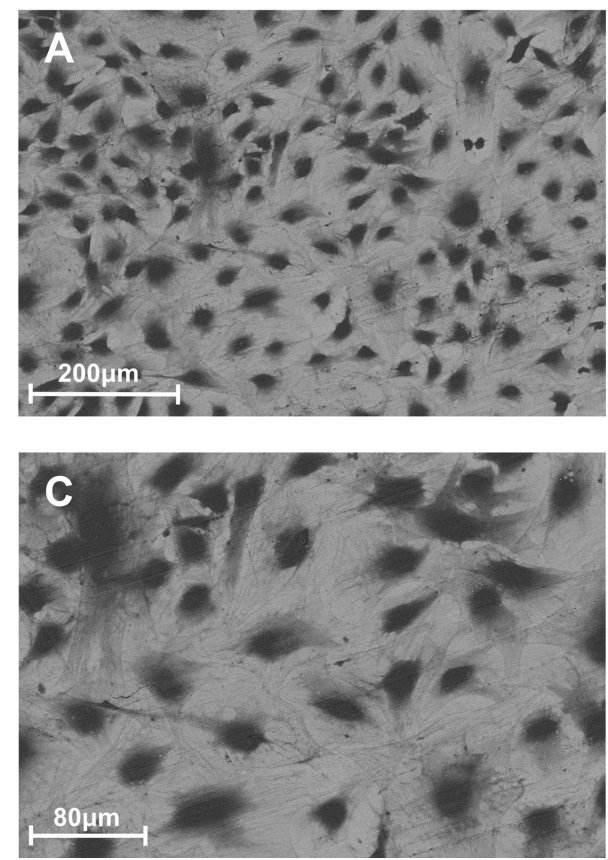

have attempted to apply various surface treatments to the implant material to increase their success and survival rate; osseointegration and cell proliferation increased because of the increase of the surface roughness by treating the surface of the implant. ${ }^{36}$ Electrochemical surface treatment ${ }^{37}$ or application of an antibacterial material coatings have been also employed to reduce bacterial adhesion. ${ }^{8}$

Recently, several studies have exhibited an increased antibacterial activity of $\mathrm{GO}^{40-42}$ A previous study by Liu and $\mathrm{Qiu}^{42,43}$ reported that treating surfaces with GO promoted antibiotic effects and bone activation. Additionally, Wang ${ }^{44}$ reported that GO was effective in improving the bioactivation of the surface of materials. Fallatah et $\mathrm{al}^{45}$
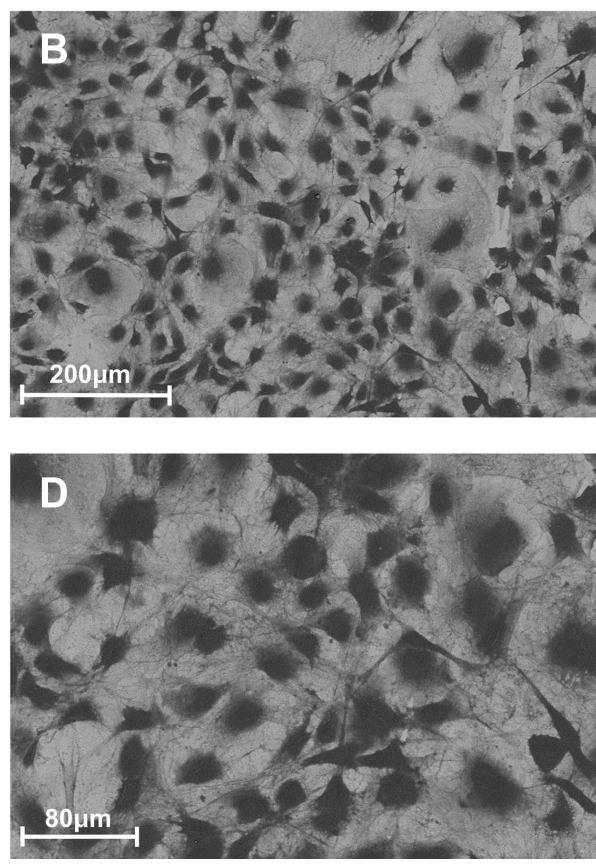

Figure 8 FE-SEM images of 5 days cell culture (A) Zr group: control group (xI50K), (B) Zr-GO group: zirconia coated with GO (xI50K), (C) Zr group: control group (x300K), (D) Zr-GO group: zirconia coated with GO (x300K). 
demonstrated that GO reduced the biofilm thickness formed by Pseudomonas putida and had an ability to separate the biofilm from the surface. In this study, GO was directly deposited using argon plasma, which was cost-effective and did not generate any by-products on the zirconia surface. The bacteria resistance and cell activation levels were evaluated by treating GO on zirconia, which has a high corrosion resistance and biocompatibility similar to titanium and esthetics similar to the natural teeth. $^{38,39}$

The mechanism of antibacterial activity of GO remains to be elucidated. The antibacterial mechanism of GO known so far is the physical destruction of the cell membrane and oxidative stress damage. ${ }^{46,47}$ In general, it is known that reactive oxygen species (ROS)-mediated oxidative stress is generated by graphene-based materials, which causes serious damage to bacterial cells and has antibacterial action. ${ }^{48,49}$ However, some studies have conducted in vitro experiments and suggested that the ROS mechanism is not the primary mechanism for the antibacterial action of GO. ${ }^{38,50}$ Another antibacterial process is the dispersibility and trapping ability of oxygen-containing functional groups of GO. ${ }^{47,51-53}$ Due to the hydrophobic properties of graphene oxide, the adhesion of bacterial cells is prevented, and furthermore, the hydrophobic interaction can destroy the bacterial membrane, resulting in antibacterial action. Additionally, aggregated GO can serve as a scaffold for bacterial attachment and proliferation. ${ }^{54}$ The antibacterial effect of GO and the effect of functional groups have received extensive attention for future studies.

In this study, S. mutans adhesion on GO-coated zirconia reduced significantly. This confirmed an antibacterial effect of GO, which aided in reducing the inflammation which might occur after the placement or restoration of zirconia implants. In addition to the antibacterial effect, the direct-deposited GO on zirconia also increased the cell activity which was effective in bone adhesion, proliferation, and differentiation. The hydrophobic and electrostatic interaction of GO improved bone differentiation resulting in its increased attention in the field of bone-tissue engineering. ${ }^{55}$ Dinescu et $\mathrm{al}^{56}$ evaluated bone differentiation by adding $3 \mathrm{wt} \%$ graphene to chitosan scaffolds and observed an increase in osteogenesis. This was attributed to the increased porosity of the surface which created a suitable environment for cell adhesion. Aidun et $\mathrm{al}^{57}$ reported that (polycaprolactone) PCL-chitosan scaffolds that were additionally treated with GO showed an increase in the cell adhesion and proliferation, and the bioactivity and hydrophilicity of the surface, while maintaining their antibacterial effect. However, in this study, a significant difference was observed in osteoblast proliferation and differentiation whereas no significant change was observed in cell adhesion. Unagolla et $\mathrm{al}^{58}$ assessed cell adhesion of PCL scaffolds which were treated with graphene at different concentrations and reported significant increase in cell proliferation over time. However, cell adhesion did not show any significant difference between groups on the 2 nd and 3rd day.

Hydrophilic surfaces exhibit increased adhesion and proliferation of bacteria and cells. In dentistry, various approaches have been applied to increase the surface hydrophilicity of implants. For example, Qu et $\mathrm{al}^{59}$ reported that the surface of implants with high hydrophilicity can improve the adhesion and differentiation of surrounding cells. In this study, the contact angle of specimens in the untreated Group $\mathrm{Zr}$ and the GOtreated Group Zr-GO was compared. Group Zr demonstrated a relatively high hydrophilicity. This surface characteristic seemed to affect the early adhesion of cells, while coating zirconia with GO did not affect early adhesion and improved cell proliferation and differentiation.

Additionally, this study examined the effects of GO coating (on a zirconia surface) on the antibacterial activity and osteoblast activation. Earlier studies attempted to coat on titanium with $\mathrm{ZrN}$ or $\mathrm{Ag}$ nanos, which is known to have antibacterial effects, and applied it to the implant abutments. ${ }^{8,60-62}$ In addition, some studies suggested that bacteria living at the interface of implant abutment and prosthesis could be prevented. ${ }^{63}$ Carinci et $\mathrm{al}^{64}$ examined bacterial viability and biofilm formation on the inside of implants coated with chlorhexidine and reported that soft tissues were effectively healed without any inflammatory symptoms. These results demonstrated that zirconia coated with GO could be employed as a fixture and abutment while placing implants in the maxillary anterior area or in the interface of implants to reduce peri-implantitis. In addition, GO coating can be applied to the inner side of zirconia to produce dental crowns with a lower occurrence of secondary caries in abutments.

\section{Conclusions}

In this study, compared to the group $\mathrm{Zr}$, the attachment of S. mutans was reduced by $58.58 \%$ and the biofilm thickness by $43.49 \%$ in the group Zr-GO. In cell evaluation, the adhesion of MC3T3-1 cells was not significant in group $\mathrm{Zr}$ and $\mathrm{Zr}$ GO, but cell proliferation and cell differentiation increased by $3.23 \%$ and $15.79 \%$, which were statistically significant.

This study confirmed the potential ability of zirconia implants coated with GO to inhibit biofilm formation and activate the cells. However, since GO has relatively low hydrophilicity compared with that of zirconia, additional research is required to increase the hydrophilicity of GO for a higher cell 
activity. Moreover, when the layer of GO is too thick, the esthetic value of zirconia reduces. Therefore, it is important to determine the required minimum thickness of GO.

\section{Acknowledgments}

This work was supported by the National Research Foundation (NRF) of Korea grant funded by the Korea government (MSIP) (No. 2020R1F1A1076982 and 2018R1A2B6002268).

\section{Disclosure}

The authors report no conflicts of interest in this work.

\section{References}

1. Han HJ, Kim S, Han DH. Multifactorial evaluation of implant failure: a 19-year retrospective study. Int $J$ Oral Maxillofac Implants. 2014;29:303-310. doi:10.11607/jomi.2869

2. Albouy JP, Abrahamsson I, Persson LG, Berglundh T. Spontaneous progression of ligatured induced peri-implantitis at implants with different surface characteristics. An experimental study in dogs II: histological observations. Clin Oral Implants Res. 2009;20:366-371. doi:10.1111/j.1600-0501.2008.01645.x

3. Carcuac O, Abrahamsson I, Albouy JP, Linder E, Larsson L, Berglundh T. Experimental periodontitis and peri-implantitis in dogs. Clin Oral Implants Res. 2013;24:363-371. doi:10.1111/clr.12067

4. Lang NP, Bragger U, Walther D, Beamer B, Kornman KS. Ligatureinduced peri-implant infection in cynomolgus monkeys. I. Clinical and radiographic findings. Clin Oral Implants Res. 1993;4:2-11. doi:10.1034/j.1600-0501.1993.040101.x

5. Sanino G, Gigola P, Putini M, Pera F, Pasarielo C. Combination therapy including seratiopeptidase improves outcomes of mechanical-antibiotic treatment of perimplantitis. Int J ImmunopatholPharmacol. 2013;26 (3):825-831. doi:10.1177/039463201302600332

6. Park SY, Kim KH, Shin SY, et al. Decontamination methods using a dental water jet and dental flos for microthreaded implant fixtures in regenerative perimplantitis treatment. Implant Dent. 2015;24 (3):307-316.

7. Schwarz F, Bieling K, Bonsman M, Latz T, Becker J. Nonsurgical treatment of moderate and advanced perimplantitis lesions: a controled clinical study. Clin Oral Investig. 2006;10(4):279-288.

8. Wan R, Chu S, Wang X, et al. Study on the osteogenesis of rat mesenchymal stem cells and the long-term antibacterial activity of Staphylococcus epidermidison the surface of silver-richTiN/Ag modified titanium alloy. J Biomed Mater Res B Appl Biomater. 2020;108 (7):3008-3021.

9. Chen H, Muller MB, Gilmore KJ, Wallace GG, Li D. Mechanically strong, electrically conductive, and biocompatible graphene paper. Adv Mater. 2008;20:3557-3561.

10. Rao CNR, Sood AK, Subrahmanyam KS, Govindaraj A. Graphene: the new two dimensional nanomaterial. Angew Chem Int Ed. 2009;48:7752-7777. doi:10.1002/anie.200901678

11. Fu C, Bai H, Zhu J, et al. Enhanced cell proliferation and osteogenic differentiation in electrospun PLGA/hydroxyapatite nanofibre scaffolds incorporated with graphene oxide. PLoS One. 2017;12: e0188352. doi: 10.1371 journal.pone. 0188352

12. Su J, Du Z, Xiao L, et al. Graphene oxide coated titanium surfaces with osteoimmunomodulatory role to enhance osteogenesis. Mater Sci Eng C Mater Bio Appl. 2020;113:110983. doi:10.1016/j.msec.2020.110983
13. Recinella L, Chiavaroli A, Giordani S, et al. Osteoblastic dierentiation on graphene oxide-functionalized titanium surfaces: an in vitro study. Nanomaterials. 2020;10:654. doi:10.3390/nano10040654

14. Nayak TR, Andersen H, Makam VS, et al. Graphene for controlled and accelerated osteogenic differentiation of human mesenchymal stem cells. ACS Nano. 2011;5:4670-4678. doi:10.1021/nn200500h

15. Zhang L, Liu W, Yue C, et al. A tough graphene nanosheet/hydroxyapatite composite with improved in vitro biocompatibility. Carbon. 2013;61:105-115. doi:10.1016/j.carbon.2013.04.074

16. Elkhenany H, Amelse L, Lafont A, et al. Graphene supports in vitro proliferation and osteogenic differentiation of goat adult mesenchymal stem cells: potential for bone tissue engineering. $J$ Appl Toxicol. 2014;35:367-374. doi:10.1002/jat.3024

17. Arshad A, Iqbal J, Siddiq M, et al. Graphene nanoplatelets induced tailoring in photocatalytic activity and antibacterial characteristics of $\mathrm{MgO} /$ graphene nanoplatelets nanocomposites. $J$ Appl Phys. 2017;121:024901. doi:10.1063/1.4972970

18. Novoselov KS. Electric field effect in atomically thin carbon films. Science. 2004;306(5696):666-669. doi:10.1126/science.1102896

19. Rümmeli MH, Rocha CG, Ortmann F, et al. Graphene: piecing it Together. Adv Mater. 2011;23:4471-4490. doi:10.1002/adma.201101855

20. Brownson DAC, Banks CE. The electrochemistry of CVD graphene: progress and prospects. Phys Chem Chem Phys. 2012;14:8264. doi: $10.1039 / \mathrm{c} 2 \mathrm{cp} 40225 \mathrm{~d}$

21. Sali S, Mackey HR, Abdala AA. Effect of graphene oxide synthesis method on properties and performance of polysulfone-graphene oxide mixed matrix membranes. Nanomaterials. 2019;9:769. doi:10.3390/ nano9050769

22. Somanathan T, Prasad K, Ostrikov KK, Saravanan A, Krishna VM. Graphene oxide synthesis from agro waste. Nanomaterials. 2015;5:826-834. doi:10.3390/nano5020826

23. Brownson DAC, Metters JP, Kampouris DK, Banks CE. Graphene electrochemistry: surfactants inherent to graphene can dramatically effect electrochemical processes. Electroanalysis. 2011;23:894-899. doi:10.1002/elan.201000708

24. Brownson DAC, Banks CE. Graphene eletrochemistry: surfactants inherent to graphene inhibit metal analysis. Electrochem Commun. 2011;13:111-113. doi:10.1016/j.elecom.2010.11.024

25. Brownson DAC, Banks CE. Fabricating graphene supercapacitors: highlighting the impact of surfactants and moieties. Chem Commun. 2012;48:1425-1427. doi:10.1039/C1CC11276G

26. Chu P, Chen JY, Wang LP, Huang N. Plasma-surface modification of biomaterials. Mater Sci Eng R Rep. 2002;36:143-206. doi:10.1016/ S0927-796X(02)00004-9

27. Park GY, Park SJ, Choi MY, et al. Atmospheric-pressure plasma sources for biomedical applications. Plasma Sources Sci Techno. 2012;21:043001. doi:10.1088/0963-0252/21/4/043001

28. Bogya ES, Károly Z, Barabás R. Atmospheric plasma sprayed silicahydroxyapatite coatings on magnesium alloy substrates. Ceram Int. 2015;41:6005-6012. doi:10.1016/j.ceramint.2015.01.041

29. Wang L, Porto CL, Palumbo F, et al. Synthesis of antibacterial composite coating containing nanocapsules in an atmospheric pressure plasma. Mater Sci Eng C Mater Biol Appl. 2021;119:111496. doi:10.1016/j.msec.2020.111496

30. Nicol MJ, Brubaker TR, Honish IIBJ, et al. Antibacterial effects of low temperature plasma generated by atmospheric-pressure plasma jet are mediated by reactive oxygen species. Sci Rep. 2020;10:3066. doi:10.1038/s41598-020-59652-6

31. Rho KH, Park C, Alam K, et al. Biological effects of Plasma-based graphene oxide deposition on Titanium. $J$ Nanomater. 2019;2019:1-7. doi:10.1155/2019/9124989

32. Chevalier J. What Future for Zirconia as a Biomaterial? Biomaterials. 2006;27:535-543. doi:10.1016/j.biomaterials.2005.07.034

33. Denry I, Kelly JR. State of the art of zirconia for dental applications. Dent Mater. 2008;24:299-307. doi:10.1016/j.dental.2007.05.007 
34. Brüll F, Van Winkelhoff AJ, Cune MS. Zirconia dental implants: a clinical, radiographic, and microbiological evaluation up to 3 years. Int J Oral Maxillofac Implants. 2014;29:914-920. doi:10.11607/ jomi.3293

35. Gautam C, Joyner J, Gautam A, Rao J, Vajtai R. Zirconia based dental ceramics: structure, mechanical properties, biocompatibility and applications. Dalton Trans. 2016;45:19194-19215. doi:10.1039/ C6DT03484E

36. Jemat A, Ghazali MJ, Razali M, Otsuka Y. Surface modifications and their effects on titanium dental implants. Biomed Res Int. 2015;2015:1-11. doi:10.1155/2015/791725

37. Yu S, Guo D, Han J, et al. Enhancing antibacterial performance and biocompatibility of pure titanium by a two-step electrochemical surface coating. ACS Appl Mater Interfaces. 2020;12(40):44433-44446. doi:10.1021/acsami.0c10032

38. Zhao M, Shan T, Wu Q, Gu L. The Antibacterial effect of graphene oxide on streptococcus mutans. J Nanosci Nanotechnol. 2020;20:2095-2103. doi:10.1166/jnn.2020.17319

39. Vi TTT, Kumar SR, Pang JHS, Liu YK, Chen DW, Lue SJ. Synergistic antibacterial activity of silver-loaded graphene oxide towards staphylococcus aureus and escherichia coli. Nanomaterials(Basel). 2020;10:366. doi:10.3390/nano10020366

40. Hu WB, Peng C, Luo WJ, et al. Graphene based antibacterial paper. ACS Nano. 2010;4:4317-4323. doi:10.1021/nn101097v

41. Zou XF, Zhang L, Wang ZJ, Luo Y. Mechanisms of the antimicrobial activities of graphene materials. J Am Chem Soc. 2016;138:2064-2077. doi:10.1021/jacs.5b11411

42. Qiu J, Geng H, Wang D, et al. Layer-number dependent antibacterial and osteogenic behaviors of graphene oxide electrophoretic deposited on titanium. ACS Appl Mater Interfaces. 2017;9:12253-12263. doi:10.1021/acsami.7b00314

43. Liu M, Hao L, Huang Q, et al. Tea polyphenol-reduced graphene oxide deposition on titanium surface enhances osteoblast bioactivity. $J$ Nanosci Nanotechnol. 2018;18(5):3134-3140. doi:10.1166/jnn.2018.14649

44. Wang C, Hu H, Li Z, et al. Enhanced osseointegration of titanium alloy implants with laser micro grooved surfaces and graphene oxide coating. ACS Appl Mater Interfaces. 2019;11:39470-39483. doi:10.1021/ acsami.9b12733

45. Fallatah H, Elhaneid M, Ali-Boucetta H, Overton TW, El Kadri H, Gkatzionis K. Antibacterial effect of graphene oxide (GO) nano-particles against Pseudomonas putida biofilm of variable age. Environ Sci Pollut Res Int. 2019;26:25057-25070. doi:10.1007/ s11356-019-05688-9

46. Li X, Li F, Gao Z, Fang L. Toxicology of graphene oxide nanosheets against paecilomyces catenlannulatus. Bull Environ Contam Toxicol. 2015;95(1):25-30. doi:10.1007/s00128-015-1499-3

47. Zou X, Zhang L, Wang Z, Luo Y. Mechanisms of the antimicrobial activities of graphene materials. J Am Chem Soc. 2016;138(7):2064-2077.

48. Zhang Y, Ali SF, Dervishi E, et al. Cytotoxicity effects of graphene and single-wall carbon nanotubes in neural phaeochromocytoma-derived PC12 cells. ACS Nano. 2010;4(6):3181-3186. doi:10.1021/nn1007176
49. Gurunathan S, Han JW, Dayem AA, et al. Antibacterial activity of dithiothreitol reduced graphene oxide. J Industrial Eng Chem. 2013;19(4):1280-1288. doi:10.1016/j.jiec.2012.12.029

50. Kurantowicz N, Sawosz E, Jaworski S, et al. Interaction of graphene family materials with Listeria monocytogenes and Salmonella enterica. Nanoscale Res Lett. 2015;10:23-34. doi:10.1186/s11671-015-0749-y

51. Liu S, Zeng TH, Hofmann M, et al. Antibacterial activity of graphite, graphite oxide, graphene oxide, and reduced graphene oxide: membrane and oxidative stress. ACS Nano. 2011;5(9):6971-6980. doi:10.1021/ nn202451x

52. Akhavan O, Ghaderi E, Esfandiar A. Wrapping bacteria by graphene nanosheets for isolation from environment, reactivation by sonication, and inactivation by near-infrared irradiation. J Phys Chem B. 2011;115(19):6279-6288. doi:10.1021/jp200686k

53. Akhavan O, Ghaderi E. Escherichia coli bacteria reduce graphene oxide to bactericidal graphene in a self-limiting manner. Carbon. 2012;50(5):1853-1860. doi:10.1016/j.carbon.2011.12.035

54. Ruiz ON, Fernando KA, Wang B, et al. Graphene oxide: a nonspecific enhancer of cellular growth. ACS Nano. 2011;5 (10):8100-8107. doi:10.1021/nn202699t

55. Hermenean A, Codreanu A, Herman H, et al. Chitosan-graphene oxide 3D scaffolds as promising tools for bone regeneration in critical-size mouse calvarial defects. Sci Rep. 2017;7:91-95. doi:10.1038/s41598017-16599-5

56. Dinescu S, Ionita M, Ignat SR, Costache M, Hermenean A. Graphene oxide enhances chitosan-based 3d scaffold properties for bone tissue engineering. Int J Mol Sci. 2019;20:5077. doi:10.3390/ijms20205077

57. Aidun A, Safaei Firoozabady A, Moharrami M, et al. Graphene oxide incorporated polycaprolactone/chitosan/collagen electrospun scaffold: enhanced osteogenic properties for bone tissue engineering. Artif Organs. 2019;43(10):E264-E281. doi:10.1111/aor.13474

58. Unagolla JM, Jayasuriya AC. Enhanced cell functions on graphene oxide incorporated 3D printed polycaprolactone scaffolds. Mater Sci Eng. 2019;102:1-11. doi:10.1016/j.msec.2019.04.026

59. Qu Z, Rausch-Fan X, Wieland M, Matejka M. Schedle A The initial attachment and subsequent behavior regulation of osteoblasts by dental implant surface modification. J Biomed Mater Res A. 2007;82:658-668.

60. Brunello G, Brun P, Gardin C, et al. Biocompatibility and antibacterial properties of zirconium nitride coating on titanium abutments: an in vitro study. PLoS One. 2018;13:e0199591.

61. Kheur S, Singh N, Bodas D, et al. Nanoscale silver depositions inhibit microbial colonization and improve biocompatibility of titanium abutments. Colloids Surf B Biointerfaces. 2017;159:151-158.

62. Slate AJ, Wickens DJ. Antimicrobial activity of Ti-ZrN/Ag coatings for use in biomaterial applications. Sci Rep. 2018;8:1497.

63. Scarano A, Valbonetti L, Degidi M, Pecci R, Piattelli A. Implantabutment contact surfaces and microgap measurements of dierent implant connections under 3-dimensional X-ray microtomography. Implant Dent. 2016;25:656-662.

64. Carinci F, Lauritano D, Bignozzi CA, et al. A new strategy against peri-implantitis: antibacterial internal coating. Int $J$ Mol Sci. 2019;20:3897.
International Journal of Nanomedicine

\section{Publish your work in this journal}

The International Journal of Nanomedicine is an international, peerreviewed journal focusing on the application of nanotechnology in diagnostics, therapeutics, and drug delivery systems throughout the biomedical field. This journal is indexed on PubMed Central, MedLine, CAS, SciSearch ${ }^{\circledR}$, Current Contents ${ }^{\mathbb{R}} /$ Clinical Medicine,
Journal Citation Reports/Science Edition, EMBase, Scopus and the Elsevier Bibliographic databases. The manuscript management system is completely online and includes a very quick and fair peer-review system, which is all easy to use. Visit http://www.dovepress.com/ testimonials.php to read real quotes from published authors. 